\title{
Evidence for significant heat losses through party wall cavities in load-bearing masonry construction
}

\author{
Short Title: Significant Heat Loss via Party Wall Cavities \\ RJ Lowe ${ }^{\mathrm{a}}$ MA PhD, J Wingfield ${ }^{\mathrm{b}}$ BSc DPhil MIMMM CEng, \\ M Bell ${ }^{b}$ DipSurv MSc, JM Bell ${ }^{b}$ MSci(Phys) \\ ${ }^{a}$ Complex Built Environment Systems Group, University College London, \\ London, UK \\ ${ }^{\mathrm{b}}$ Buildings and Sustainability Group, Leeds Metropolitan University, Leeds, UK
}

\section{Abstract}

This paper presents empirical evidence and analysis suggesting significant heat loss from air movement through cavities in party walls in masonry construction. The measurements have been made during the course of coheating tests undertaken as part of the Stamford Brook housing field trial ${ }^{(1)}$. Direct measurements show the additional heat loss may amount to up to $30 \%$ of total heat loss in the dwellings tested, potentially making it the largest single contributor to heat loss in terraced dwellings built to the 2006 revision of the Building Regulations. The phenomenon of convective bypassing associated with masonry party walls was identified in the late 1970s in the course of the Twin Rivers Project ${ }^{(2,3)}$, albeit in a somewhat different construction from that used at Stamford Brook. A similar phenomenon was reported by Siviour ${ }^{(4)}$ in

\footnotetext{
${ }^{a}$ Address for correspondence: R Lowe, The Bartlett School of Graduate Studies, 1-19 Torrington Place, University College London, Gower Street, London, WC1E 6BT, UK. Telephone: +44(0)20-76795916, E-mail: robert.lowe@ucl.ac.uk
} 
Pre-refereeing version July 2006. Revised version subsequently published in Building Services Engineering Research and Technology 282 (2007), 161-181.

the UK in the mid 1990s, but it appears that no action was taken either to confirm his results, to develop simple technical fixes to eliminate this large additional heat loss mechanism, or to amend standards for calculating heat losses from buildings. There are no references to heat loss associated with party walls in current conventions for heat loss calculation ${ }^{(5,6)}$, and we have found no other recent literature on this subject.

\section{Practical Application}

The heat bypass mechanism described in this paper is believed by the authors to contribute to a significant proportion of heat loss from buildings in the UK constructed with clear cavities such as those found in separating walls between cavity masonry dwellings. It is proposed that relatively simple design changes could be undertaken to eliminate such heat loss pathways from new buildings. In addition, simple and cost effective measures are envisaged that could be used to minimise or eliminate the phenomenon from existing buildings. Such an approach could give rise to a significant reduction in carbon emissions from UK housing. 
Pre-refereeing version July 2006. Revised version subsequently published in Building Services Engineering Research and Technology 282 (2007), 161-181.

\section{List of Symbols}

\begin{tabular}{|c|c|}
\hline$A_{\text {roof }}$ & plan area of roof $\left(\mathrm{m}^{2}\right)$ \\
\hline$c_{f}$ & $d w e l l i n g$ fabric heat loss coefficient $\left(W K^{-1}\right)$ \\
\hline$c_{p}$ & heat capacity air at constant pressure $\approx 1000 \mathrm{Jkg}^{-1} \mathrm{~K}^{-1}$ \\
\hline$c_{v}$ & dwelling ventilation heat loss coefficient $\left(W K^{-1}\right)$ \\
\hline$d$ & dwelling plan depth $(m)$ \\
\hline$D_{h}$ & hydraulic diameter $(m)$ \\
\hline$f$ & friction factor \\
\hline$g$ & acceleration due to gravity $\left(\mathrm{ms}^{-2}\right)$ \\
\hline$H$ & height of cavity $(m)$ \\
\hline$h_{\text {loft floor }}$ & thermal conductance of loft floor $\left(W m^{-2} K^{-1}\right)$ \\
\hline$h_{\text {roof covering }}$ & thermal conductance of roof covering $\left(W^{-2} K^{-1}\right)$ \\
\hline$I_{\text {eave }}$ & length of eaves $(m)$ \\
\hline$I_{\text {party wall }}$ & length of party walls $(\mathrm{m})$ \\
\hline$L_{\text {bypass }}$ & loft bypass heat transfer coefficient $\left(W K^{-1}\right)$ \\
\hline$L_{\text {loft edges }}$ & loft edge heat transfer coefficient $\left(W K^{-1}\right)$ \\
\hline$L_{\text {loft floor }}$ & loft floor heat transfer coefficient $\left(W K^{-1}\right)$ \\
\hline$L_{\text {roof covering }}$ & roof covering heat transfer coefficient $\left(W K^{-1}\right)$ \\
\hline$n$ & background ventilation rate (air changes $h^{-1}$ ) \\
\hline Q & daily mean heating power $(W)$ \\
\hline Q' & corrected daily mean heating power (W) \\
\hline$q_{50}$ & dwelling air permeability ( $m h^{-1} @ 50$ Pa) \\
\hline$R$ & effective solar aperture $\left(m^{2}\right)$ \\
\hline $\operatorname{Re}$ & Reynolds number \\
\hline$S$ & solar insolation $\left(\mathrm{Wm}^{-2}\right)$ \\
\hline$T_{\text {cavity }}$ & party wall cavity temperature $\left({ }^{\circ} \mathrm{C}\right)$ \\
\hline$T_{\text {in }}$ & internal temperature $\left({ }^{\circ} \mathrm{C}\right)$ \\
\hline$T_{\text {loft }}$ & loft temperature $\left({ }^{\circ} \mathrm{C}\right)$ \\
\hline$T_{\text {out }}$ & external temperature $\left({ }^{\circ} \mathrm{C}\right)$ \\
\hline$U_{\text {cavity-loft }}$ & conductance from party wall cavity into loft $\left(\mathrm{Wm}^{-2} \mathrm{~K}^{-1}\right)$ \\
\hline
\end{tabular}


Pre-refereeing version July 2006. Revised version subsequently published in Building Services Engineering Research and Technology 282 (2007), 161-181.

$\begin{array}{ll}U_{\text {roof effective }} & \text { effective } U \text {-value of roof }\left(\mathrm{Wm}^{-2} \mathrm{~K}^{-1}\right) \\ U_{\text {roof notional }} & \text { notional } U \text {-value of roof }\left(\mathrm{Wm}^{-2} \mathrm{~K}^{-1}\right) \\ v & \text { upward speed of air in party wall cavity }\left(\mathrm{ms}^{-1}\right) \\ W_{\text {cavity }} & \text { width of party wall cavity }(\mathrm{m}) \\ \Delta P_{f} & \text { pressure drop due to friction in party wall cavity }(\mathrm{Pa}) \\ \Delta P_{\text {stack }} & \text { stack pressure difference }(\mathrm{Pa}) \\ \Delta T & \text { inside-outside temperature difference }(\mathrm{K}) \\ \varepsilon & \text { absolute roughness of party wall cavity }(\mathrm{m}) \\ \rho & \text { density of air } \approx 1.2 \mathrm{kgm}^{-3} \\ \Psi_{\text {eave }} & \text { linear thermal transmittance eaves }\left(\mathrm{Wm}^{-1} \mathrm{~K}^{-1}\right) \\ \Psi_{\text {party wall }} & \text { linear thermal transmittance party wall }\left(\mathrm{Wm}^{-1} \mathrm{~K}^{-1}\right)\end{array}$


Pre-refereeing version July 2006. Revised version subsequently published in Building Services Engineering Research and Technology 282 (2007), 161-181.

\section{Introduction}

The work described here has been undertaken as part of the Stamford Brook Housing Field Trial, involving the construction of some 700 dwellings on a site close to Manchester in the North West of England. The project is being undertaken by a partnership that includes two large housebuilders, Redrow Homes and Bryant Homes (a subsidiary of Taylor Woodrow), the National Trust and Leeds Metropolitan University Buildings and Sustainability Group, with support from the DCLG ${ }^{a}$ and DTI - the departments of state responsible for energy and industrial policy in the UK. The first phase of the project is being built to a comprehensive Environmental Performance Standard, developed by the project partners over a period of two years. This should result in houses with annual $\mathrm{CO}_{2}$ emissions $5-10 \%$ lower than dwellings compliant with the 2006 revision of the Building Regulations for England \& Wales ${ }^{(7,8)}$.

The houses at Stamford Brook are built in load-bearing masonry construction. The first dwellings were completed and occupied early in 2005. The monitoring programme began in the autumn of 2005 . As well as long term monitoring of occupied dwellings, it includes co-heating and pressurisation tests in

\footnotetext{
${ }^{a}$ The Department for Communities and Local Government, previously the Office of the Deputy Prime Minister, ODPM. References produced before the change of name are listed under ODPM.
} 
Pre-refereeing version July 2006. Revised version subsequently published in Building Services Engineering Research and Technology 282 (2007), 161-181.

unoccupied dwellings ${ }^{b}$. The results presented in this paper are based on coheating tests carried out on two houses, referred to as houses $A$ and $E^{c}$, in November 2005 and from December 2005 to March 2006 respectively. Measurements of temperature in the loft of the first of these houses provided evidence of heat loss significantly in excess of predictions, and measurements of the surface temperature of the party wall provided an initial indication that this discrepancy was associated with the party walls. A review of these initial indications by the Project Advisory Group led to the extension of the second co-heating test on house $\mathrm{E}$.

Results from this second extended test form the core of this paper. A full report on the post construction testing is provided in project interim report number $5^{(9)}$.

\section{Dwelling form and construction}

The Stamford Brook development consists of a mix of single storey apartments and two and three storey houses, with the latter predominantly arranged in short terraces. A detailed description of the dwellings is contained in interim

\footnotetext{
${ }^{\mathrm{b}}$ Difficulties in the recruitment of households have delayed the long term monitoring programme to 2007 but, fortuitously, this has provided the capacity for a more detailed investigation of the party wall heat loss issues discussed in this paper with further coheating tests (incorporating a more detailed measurements) planned for the winter of 2006/07.

${ }^{c}$ House $A$ is an end-of-terrace house with one adjacent house. House $E$ is a midterrace house with two adjacent houses, D and F.
} 
Pre-refereeing version July 2006. Revised version subsequently published in Building Services Engineering Research and Technology 282 (2007), 161-181.

reports on the design and construction process ${ }^{(10,11)}$. This section of the paper presents a short summary of the main features of the construction.

\subsection{Walls including party walls}

As noted above, walls are load-bearing masonry, with an inner leaf of $100 \mathrm{~mm}$ thick medium density blockwork $\left(1400 \mathrm{kgm}^{-3}\right)$, a $142 \mathrm{~mm}$ cavity fully-filled with mineral fibre and an outer leaf of $100 \mathrm{~mm}$ thick brickwork. Inner and outer leaves are connected structurally using glass-filled polyester wall ties. The $U$ value calculated for this construction ${ }^{(9)}$ is approximately $0.23 \mathrm{Wm}^{-2} \mathrm{~K}^{-1}$.

The primary air barrier in the walls consists of a sprayed and hand-applied parging layer, approximately $5 \mathrm{~mm}$ thick of cementitious material ${ }^{(12)}$. This layer is applied directly to the inside surface of the blockwork before the application of the final surface finish of plasterboard ${ }^{(12)}$. The parging layer is applied to all walls, including party wall and internal masonry partitions. The effect of parging, together with improved detailing throughout the thermal envelope, training and site supervision has been air permeabilities in the range 1.7 to 9.7 $\mathrm{mh}^{-1} @ 50 \mathrm{~Pa}$ with a mean of $4.9 \pm 1.8$. This is less than half the leakage of typical domestic masonry construction in the $\mathrm{UK}^{(13,14)}$.

Party wall construction is a variant of external wall construction. Party walls consist of two leaves of blockwork, parged and plasterboarded as described 
Pre-refereeing version July 2006. Revised version subsequently published in Building Services Engineering Research and Technology 282 (2007), 161-181.

above, separated by a clear, unfilled cavity. This cavity is $142 \mathrm{~mm}$ wide in the Bryant houses and $75 \mathrm{~mm}$ in the Redrow houses. Its primary purpose is to prevent sound transmission, particularly impact sound transmission across the wall $^{(15)}$. This requires the cavity to be continuous and unbridged. Part $L$ of the Building Regulations for England \& Wales ${ }^{(7,16)}$ imposes no thermal requirements on masonry party walls, on the assumption that the temperatures of adjacent dwellings will be similar, and no requirement to limit the flow of external air though the cavity ${ }^{d}$. External and party wall constructions at Stamford Brook are shown in Figure1.

\subsection{Roof}

Roofs of houses $\mathrm{A}$ and $\mathrm{E}$ are conventional trussed rafter constructions, insulated with $250 \mathrm{~mm}$ of cellulose fibre blown onto the loft floor. The roofs are covered with a roof membrane, and interlocking tiles on wooden battens. This construction gives a nominal $\mathrm{U}$ value of $0.14 \mathrm{Wm}^{-2} \mathrm{~K}^{-1}$. Party walls rise through the unheated roof void, stopping a few centimetres below the roof membrane. The gap between the membrane and the top of the party wall is fire-stopped with mineral wool.

\footnotetext{
${ }^{d}$ The Building Regulations do limit the leakage of air from each dwelling into the cavity though an overall limit on dwelling permeability.
} 
Pre-refereeing version July 2006. Revised version subsequently published in Building Services Engineering Research and Technology 282 (2007), 161-181.

\subsection{Ground and intermediate floors}

Ground floors are concrete slabs cast in-situ on $100 \mathrm{~mm}$ of closed cell plastic foam insulation, giving a $U$ value of approximately $0.17 \mathrm{Wm}^{-2} \mathrm{~K}^{-1}$.

\subsection{Windows and doors}

Windows are double glazed in softwood frames with a nominal whole window

$\mathrm{U}$ Value of just over $1.3 \mathrm{Wm}^{-2} \mathrm{~K}^{-1}$. The same glazing is used in doors, in addition to insulated opaque panels.

\subsection{Dimensions of the co-heating test dwellings}

Table 1 and Figures 2 and 3 summarise the form and dimensions of the coheating test houses.

\subsection{Predicted heat loss coefficients}

Ventilation rates $n$ were estimated using a variant of the $1 / 20$ rule-of-thumb: 
Pre-refereeing version July 2006. Revised version subsequently published in Building Services Engineering Research and Technology 282 (2007), 161-181.

$n=0.85 .950 / 20\left(\right.$ air changes $\left.\mathrm{h}^{-1}\right)$

where 0.85 is an allowance for the protection provided by adjacent and nearby houses.

Air permeabilities were measured before and after the co-heating tests. The results are set out in Table 2 .

Fabric heat loss coefficients were calculated from element areas and $U$ values, junction lengths and linear thermal transmission coefficients. All heat loss coefficients $^{\mathrm{e}}$ are summarised in Table 3 .

\section{Methods of investigation}

\subsection{Co-heating test}

A co-heating test involves heating the inside of a house to a constant temperature (typically $25^{\circ} \mathrm{C}$ ) over a period of at least a week using electrical resistance heaters. Correlation of electrical heat input with external temperature and insolation then allows estimation of the total heat loss

\footnotetext{
${ }^{e}$ The higher-than-normal inside-outside temperature difference during the co-heating tests implies that background ventilation rates and ventilation heat loss coefficients during these tests are likely to have exceeded those in the table. Calculations based on a semi-analytical model of air flow ${ }^{(17)}$ suggest that the increase is of the order of $3 \mathrm{WK}^{-1}(10 \%)$ for the two storey house $\mathrm{A}$ and $15 \mathrm{WK}^{-1}(27 \%)$ for the 3 storey house $\mathrm{E}$.
} 
Pre-refereeing version July 2006. Revised version subsequently published in Building Services Engineering Research and Technology 282 (2007), 161-181.

coefficient and effective solar aperture. The procedure was originally described by Palmiter et al ${ }^{(18)}$. A detailed description of the tests at Stamford Brook is presented by Wingfield et $\mathrm{al}^{(9)}$. A summary of the co-heating test rig is presented in Tables 4 and 5 .

\subsection{Infra-red survey}

A FLIR Systems Thermacam P65 model, with a 320x240 pixel array, a thermal sensitivity of $0.08^{\circ} \mathrm{C}$ at $30^{\circ} \mathrm{C}$ and spectral range of $7.5-13 \mu \mathrm{m}$, was used to observe the surface temperatures of the main elements of the two test houses during the co-heating tests. Imaging was carried out from both outside and inside the dwelling and also from inside the attic space.

\subsection{Direct temperature measurements in party wall cavity}

The temperature of the party wall cavity was measured with small datalogging temperature-humidity sensors attached to lengths of wire, pushed through the gap between the party wall and roof, and lowered down into the cavity to a predetermined level. The sensors were Tinytag Ultra TGU 1500 dual channel temperature humidity sensors manufactured by Gemini Dataloggers Ltd, with external dimensions $72 \mathrm{~mm} \times 60 \mathrm{~mm} \times 33 \mathrm{~mm}$. 
Pre-refereeing version July 2006. Revised version subsequently published in Building Services Engineering Research and Technology 282 (2007), 161-181.

\section{Results}

\subsection{Predicted versus measured heat loss coefficients}

The primary results of the co-heating tests are scatter plots of the heat input needed to maintain a constant internal temperature versus the inside-outside temperature difference. All quantities have been averaged over successive 24 hour periods. Figures 4 and 5 show both uncorrected data and data corrected for solar radiation. The corrected daily mean heating power (an estimate of the daily mean heating power at zero insolation ${ }^{f}$ ) is given by:

$Q^{\prime}=Q-R \cdot S$

where $R$ is the effective solar aperture calculated by multiple regressions of daily mean heating power $Q$ against inside-outside temperature difference $\Delta T$ and insolation $S$, with regressions forced through the origin.

The results of these regressions are summarised in Table 6 below. It is apparent both from Figures 4 and 5 and from Table 6 that measured heat

\footnotetext{
${ }^{f}$ Note that the correction is only used to improve the graphical presentation of the data. The heat loss coefficient is calculated directly from multiple regression of heating power against $\Delta T$ and $S$.
} 
Pre-refereeing version July 2006. Revised version subsequently published in Building Services Engineering Research and Technology 282 (2007), 161-181.

losses are higher than calculated. In the case of house E, the excess heat loss is between $1400-2000 \mathrm{~W}$ over the period shown.

The calculated $\mathrm{U}$ value of the party wall is $1.1 \mathrm{Wm}^{-2} \mathrm{~K}^{-1}$. With a temperature difference of approximately $5 \mathrm{~K}$ between house $\mathrm{E}$ and the adjacent dwellings, the predicted house-to-house heat flow would be of the order of $600 \mathrm{~W}$. This is insufficient to explain the observed discrepancy between predicted and measured heat loss from house $\mathrm{E}$ during the co-heating test.

\subsection{Surface temperatures of party walls in lofts}

As noted earlier the first indication of anomalous behaviour in the test houses came from infra-red images of the party wall in house A. However, the clearest images come from house E. Some of these are shown below in Figures 6 and 7.

The key features of these images are:

- the presence of a high temperature strip at the bottom of the wall, immediately above the insulation layer (Figure 7) - this is consistent with the thermal bridge between loft space and the room below, caused by the blockwork bypassing the insulation on the loft floor; 
Pre-refereeing version July 2006. Revised version subsequently published in Building Services Engineering Research and Technology 282 (2007), 161-181.

- surface temperatures in the range $13-14^{\circ} \mathrm{C}$ in the middle part of the triangle of blockwork - this was wholly unexpected;

- temperatures of around $17^{\circ} \mathrm{C}$ in the top metre or so of the wall - again wholly unexpected;

- the higher temperature of mortar joints compared with surrounding blockwork, seen particularly clearly in Figure 7.

Similar images were obtained for the other party wall in this loft (E-D).

\subsection{Extended time series including loft and party wall cavity temperatures}

The final broad category of empirical evidence is provided by extended time series data including temperatures in the loft void and in the party wall cavity. The main extended data set consists of the following measurements made at ten minute intervals over an 11 day period from 9 -19 February inclusive:

- inside temperature;

- outside air temperature and insolation;

- the temperature in the loft void of test house $E$ just above the insulation then at $1.0 \mathrm{~m}$ and $1.5 \mathrm{~m}$ from the top of the insulation together with single point temperature in the loft of house $F$ for 4 days from 16 to 19 February; 
Pre-refereeing version July 2006. Revised version subsequently published in Building Services Engineering Research and Technology 282 (2007), 161-181.

- temperatures in the cavity of the party wall separating houses $E \& D$ and $E \& F$, at $0.5 \mathrm{~m}$ below insulation level and $1.0 \mathrm{~m}$ above.

Measurements were accompanied by further infra-red imaging. The daily mean temperatures over the 11 days are shown in Figure 8.

The data from the three temperature sensors in the loft of house $E$ indicate temperature stratification, with a tendency to higher temperatures towards the top of the loft with a mean of $15.1^{\circ} \mathrm{C}$ at $1.5 \mathrm{~m}$ above the ceiling, $12.7^{\circ} \mathrm{C}$ at 1.0 $\mathrm{m}$ and $11.7^{\circ} \mathrm{C}$ at $0.25 \mathrm{~m}$. Over the eleven days the degree of stratification tended to decrease as the mean temperature in the loft increased.

The key features of these results are:

- Temperatures generally were steady ${ }^{(9)}$. Loft temperature follows external air temperature closely and is largely unaffected by variation in insolation (e.g. 10-12 February).

- Following stabilisation of the internal temperature at around $27^{\circ} \mathrm{C}$, the attic space was, on average between $8 \mathrm{~K}$ and $9 \mathrm{~K}$ warmer than the outside temperature over the test period (mean external temperature $=$ $4.8^{\circ} \mathrm{C}$ ). This difference is larger, by a factor of around 8 , than the $1.1 \mathrm{~K}$ that would be predicted on the basis of a simple model of heat transfer described below. It should be noted also that the mean loft temperature in house $\mathrm{F}$ for the four days at the end of the monitoring period $\left(9.9^{\circ} \mathrm{C}\right)$ 
Pre-refereeing version July 2006. Revised version subsequently published in Building Services Engineering Research and Technology 282 (2007), 161-181.

was some $3 \mathrm{~K}$ lower than over the same four days in house $\mathrm{E}$. This is consistent with the fact that house $F$ is an end-of-terrace with only one party wall, while house $\mathrm{E}$ has two party walls.

- The mean temperatures inside the attic party wall cavities ranged from some $21^{\circ} \mathrm{C}$ below insulation level to $18^{\circ} \mathrm{C}$ above the insulation level over the measurement period. The temperature difference between the cavity and the dwellings adjacent to house E would be associated with a heat flux of at most $500 \mathrm{~W}$. House-to-house heat flux therefore accounts for less than one quarter of the difference between measured and predicted heat loss from house $E$ and fails completely to explain the observed loft temperature excess.

- The high temperatures and temperature gradient in the cavity are consistent with an upward flow of warm air, heating the loft space via conduction through the leaves of blockwork and by the movement of warm air through gaps in the blockwork and through the junction between the party wall and the roof. The observed temperatures are broadly in line with both the infra-red data (Figures 6 and 7) and a set of preliminary measurements taken in the party wall between dwellings $E$ and $\mathrm{F}$. 
Pre-refereeing version July 2006. Revised version subsequently published in Building Services Engineering Research and Technology 282 (2007), 161-181.

\section{Analysis and discussion of possible physical mechanisms}

The results set out above suggest that the roof insulation in the co-heating test houses was being bypassed by heat flowing up the cavities of the party walls. The purpose of this section of the paper is to analyse the data in more detail to see whether it supports the thermal bypass model.

\subsection{Comparison of expected and measured temperatures in the loft}

Figure 9 shows two simple models of heat flows between the inside and the outside of a dwelling through the loft.

Approximate values of the heat transfer coefficients are presented below:

$$
\begin{aligned}
& L_{\text {roof covering }}=A_{\text {roof }} \cdot h_{\text {roof covering }} \approx 35.2 \times 4.2 \approx 147 \\
& L_{\text {loft floor }}=A_{\text {roof }} \cdot h_{\text {loft floor }} \approx 35.2 \times 0.14 \approx 5.0 \\
& L_{\text {loft edges }}=2 .\left(I_{\text {eave }} \cdot \psi_{\text {eave }}+I_{\text {party wall }} \psi_{\text {party wall }}\right) \approx 2 \times(6.9 \times 0.13+5.1 \times 0.023) \approx 1.9(5)
\end{aligned}
$$

Solving the equation implied in Figure 9(a) for $T_{\text {loft }}$ we get:

$$
T_{\text {loft }} \approx T_{\text {out }}+\left(T_{\text {in }}-T_{\text {out }}\right) \cdot\left(L_{\text {loft floor }}+L_{\text {loft edges }}\right) / L_{\text {roof covering }}
$$


Pre-refereeing version July 2006. Revised version subsequently published in Building Services Engineering Research and Technology 282 (2007), 161-181.

Using the values for house $E$ (Equations 3, 4 and 5), the loft temperature can be estimated from equation 7 .

$T_{\text {loft }} \approx T_{\text {out }}+0.05 .\left(T_{\text {in }}-T_{\text {out }}\right)$

The implication of this analysis is that under the conditions during the eleven day period from $9-19$ February illustrated in Figure 8 (mean $T_{\text {in }}-T_{\text {out }}$ of $22.5^{\circ} \mathrm{C}$ ), we would expect the loft temperature to be within $1.1 \mathrm{~K}$ of the outside temperature. The fact that loft-outside temperature difference is almost eight times as great is clear evidence of one or more additional heat transfer mechanisms between the inside of the house and the loft. It is worth noting that the predicted loft temperature is strongly influenced by the assumed rate of heat transfer from the loft to outside, $h_{\text {roof covering. }}$ Our estimate for this coefficient, which includes the resistance of the loft void, is taken from BS EN ISO $6946^{(6)}$. The actual value is unlikely to be smaller than this ${ }^{g}$.

The size of the bypass coefficient $L_{\text {bypass }}$ required to explain the observed loft temperature can be estimated. Firstly we will define the temperature difference ratio for the loft:

$\phi_{\text {loft }}=\left(T_{\text {loft }}-T_{\text {out }}\right) /\left(T_{\text {in }}-T_{\text {out }}\right)$

\footnotetext{
${ }^{\mathrm{g}}$ In accordance with this standard, $A_{\text {roof }}$ refers to the plan area of the roof.
} 
Pre-refereeing version July 2006. Revised version subsequently published in Building Services Engineering Research and Technology 282 (2007), 161-181.

$$
\begin{aligned}
& \phi_{\text {loft }}=\frac{1}{\frac{L_{\text {roof cov ering }}}{\left(L_{\text {loft floor }}+L_{\text {loft edges }}+L_{\text {bypass }}\right)}+1} \\
& \phi_{\text {loft }}=\frac{\left(L_{\text {loft floor }}+L_{\text {loft edges }}+L_{\text {bypass }}\right)}{\left(L_{\text {loft floor }}+L_{\text {loft edges }}+L_{\text {bypass }}+L_{\text {roof cov ering }}\right)} \\
& \phi_{\text {loft } \cdot\left(L_{\text {loft floor }}+L_{\text {loft edges }}+L_{\text {bypass }}+L_{\text {roof covering }}\right)=\left(L_{\text {loft floor }}+L_{\text {loft edges }}+L_{\text {bypass }}\right)} \\
& \left(1-\phi_{\text {loft }}\right) \cdot L_{\text {bypass }}=\phi_{\text {loft }} \cdot\left(L_{\text {loft floor }}+L_{\text {loft edges }}+L_{\text {roof covering }}\right)-\left(L_{\text {loft floor }}+L_{\text {loft edges }}\right) \\
& L_{\text {bypass }}=\frac{\phi_{\text {loft }} \cdot\left(L_{\text {loft floor }}+L_{\text {loft edges }}+L_{\text {roof covering }}\right)-\left(L_{\text {loft floor }}+L_{\text {loft edges }}\right)}{\left(1-\phi_{\text {loft }}\right)}
\end{aligned}
$$

With the observed temperature difference ratio of approximately 0.44

$$
L_{\text {bypass }} \approx 126
$$

Since the additional heat loss takes place through the roof covering, it is natural to express it as an effective $U$ value for the roof. This effective $U$ value is given by:

$$
U_{\text {roof effective }}=\phi_{\text {loft }} \cdot h_{\text {roof cov ering }} \approx 1.8 \mathrm{Wm}^{-2} \mathrm{~K}^{-1}
$$

This is more than an order of magnitude larger than the notional $U$ value and a factor of 9 higher than the combined loss through the loft floor and the thermal 
Pre-refereeing version July 2006. Revised version subsequently published in Building Services Engineering Research and Technology 282 (2007), 161-181.

bridges associated with eaves and junctions between party walls and roof insulation. The additional heat loss increases the total heat loss coefficient of the house by:

$A_{\text {roof }} \cdot\left(U_{\text {roof effective }}-U_{\text {roof notional }}\right) \approx 60 \mathrm{WK}^{-1}$

This is of the same order as the observed discrepancy in the total heat loss coefficient for house $\mathrm{E}$ given in Table $6\left(78 \mathrm{WK}^{-1}\right)$.

It is possible to postulate three bypass mechanisms:

- air leaks through the loft floor;

- thermal bridging in addition to that already accounted for in relation to the eaves and party wall-ceiling junctions;

- heat transfer associated with the party wall.

In the case of the first possible mechanism; to account for the whole of the observed bypass coefficient via air leakage through the loft floor, the total flow of air between the upper storey and the loft would have to exceed the expected total background ventilation rate for the house by a factor in excess of 2 . However, if half of the exfiltration from the dwelling passed though the roof, this would account for a quarter of the bypass coefficient. We consider it likely but not certain that the scale and possible concentration of air leakage paths that would be required to account for the local heating observed would have been 
Pre-refereeing version July 2006. Revised version subsequently published in Building Services Engineering Research and Technology 282 (2007), 161-181.

detected with the infra-red camera. Similarly, if the second mechanism were to be significant, it is likely that unaccounted for conductive thermal bridging would be detected also in the infra-red images.

We strongly suspect that the first two possible heat loss mechanisms account for part of the observed loft temperature excess. But the empirical evidence for them is weak and indirect and they are unlikely to account for the whole of the excess. We therefore turn to evidence for heat transfer associated with the party wall.

\subsection{Evidence for heat flow from the party wall into the loft}

The observation (Figure 7) that temperature of mortar in the party wall in the loft space was higher than the temperature of the surrounding blockwork is direct qualitative evidence that the direction of heat flow is from the cavity into the attic. This is because the conductivity of the mortar is roughly $50 \%$ higher than that of medium density concrete blocks ( 0.9 compared with $\left.0.5 \mathrm{Wm}^{-1} \mathrm{~K}^{-1}\right)$. Based on the observed temperatures in the loft and party wall cavity and the calculated heat transfer coefficient through one leaf of blockwork, we estimate the total rate of conduction of heat into the loft space from both party wall cavities above the plane of the loft floor to be in the region of $50 \mathrm{WK}^{-1}$, where the driving temperature difference is given approximately by: 
Pre-refereeing version July 2006. Revised version subsequently published in Building Services Engineering Research and Technology 282 (2007), 161-181.

$$
1 / 4\left(T_{\text {in } D}+2 . T_{\text {in } E}+T_{\text {in } F}\right)-T_{\text {loft }}
$$

where:

$T_{\text {in } D}, T_{\text {in } E}$ and $T_{\text {in } F}$ are the internal temperatures of houses $\mathrm{D}, \mathrm{E}$ and $\mathrm{F}$.

This accounts for approximately $40 \%$ of the observed bypass coefficient. We therefore seek an additional heat transfer mechanism from the party wall cavity into the loft.

\subsection{Empirical evidence for air flow from the party wall cavity into the loft}

Direct evidence for air flow over the top of the party and into the loft space is provided by the infra-red images of high surface temperatures in the loft void adjacent to the top of the party wall - these temperatures are close to the temperature of air in the upper part of the party wall cavity itself (Figure 6).

Indirect evidence for air movement up the party wall cavity is provided by:

- the fact that the air in the cavity below the plane of the loft floor is not in thermal equilibrium with the internal temperatures of the houses on either side - the temperature at this point is typically $2 \mathrm{~K}$ less than the mean of internal temperatures of the adjacent houses; 
Pre-refereeing version July 2006. Revised version subsequently published in Building Services Engineering Research and Technology 282 (2007), 161-181.

- the fact that, above the plane of the loft floor, temperatures in the party wall cavity tend to fall with increasing height;

- the observed stratification in the loft, with higher temperatures at the top, suggesting a warm air input into the loft void.

The presence of a gap connecting the top of the cavity directly to the loft void is crucial to this argument. It was not possible to measure the width of this gap directly, but it is clearly at least as wide as the Tinytag sensors (smallest dimension $33 \mathrm{~mm}$ ) that were passed through it to measure temperatures in the cavity. Given that there is an equal gap on each side of the party wall, the total cross section of gap from the cavity into the lofts on either side is not appreciably smaller than the width of the cavity itself. The air flow path at this point is only blocked by the mineral wool firestopping, which is not an effective air barrier ${ }^{(19)}$. Once the air reaches the top of the party wall cavity, it is likely that most passes into the loft void. The continuity of the roof membrane across the party wall will prevent direct leakage to outside.

The rate of fall of temperature in the upper part of the party wall cavity can be used to estimate the speed of air moving up the cavity. Here we assume that convective flows within the cavity are weak and that air flow in the cavity is uniformly upward. Temperature in the cavity will fall as heat is conducted through the blockwork into the lofts on either side of the wall. The upward speed of air in the cavity is then given by: 
Pre-refereeing version July 2006. Revised version subsequently published in Building Services Engineering Research and Technology 282 (2007), 161-181.

$$
v=\frac{U_{\text {cavity-loft }} \cdot\left(\left(T_{\text {cavity }}-T_{\text {loft } D}\right)+\left(T_{\text {cavity }}-T_{\text {loft } E}\right)\right)}{d T_{\text {cavity }}}
$$

The rate of fall of temperature in the upper part of the party wall cavity, under the conditions of the co-heating test, is approximately $0.8 \mathrm{Km}^{-1}$. With $U_{\text {cavity-loft }} \approx 2.4 \mathrm{Wm}^{-2} \mathrm{~K}^{-1}$

and

$$
w_{\text {cavity }} \approx 0.075 \mathrm{~m}
$$

we deduce that air moves up the party wall cavity at approximately $0.4 \mathrm{~ms}^{-1}$.

The mass flow up each cavity is assumed to split equally between adjacent lofts. Where, as in house E, a house has two party walls, the total volume flow into the loft is in the order of $d \cdot w_{\text {cavity }} \cdot v \approx 0.15 \mathrm{~m}^{3} \mathrm{~s}^{-1}$, where $d$ is the depth of the house plan, $6.9 \mathrm{~m}$.

The accompanying heat flow is somewhat more difficult to estimate. The temperature of air flowing into the loft was measured, but the temperature of air flowing out of the loft was not. If we assume that the quantity that we have referred to as $T_{\text {loft } E}$ represents the temperature of outflowing air, then:

$$
Q \approx c_{p} \cdot \rho \cdot d \cdot w_{\text {cavity }} \cdot v \cdot\left(T_{\text {cavity }}-T_{\text {loft }}\right) \approx 820 \mathrm{~W}
$$


Pre-refereeing version July 2006. Revised version subsequently published in Building Services Engineering Research and Technology 282 (2007), 161-181.

The corresponding bypass heat transfer coefficient is given by:

$$
\frac{Q}{1 / 4\left(T_{\text {in } D}+2 . T_{\text {in } E}+T_{\text {in } F}\right)-T_{\text {loft }}} \approx 78 \mathrm{WK}^{-1}
$$

Together with the $50 \mathrm{WK}^{-1}$ derived earlier for conduction through the blockwork of the party walls into the loft, we have identified mechanisms that account for the whole of the $126 \mathrm{WK}^{-1}$ bypass coefficient needed to explain the observed loft temperature excess. That most of this depends on air flow up the cavity requires us next to analyse the forces that might produce such a flow.

\subsection{Analysis of bulk air movement in party wall cavity}

The steadiness of the temperatures plotted in Figure 8 suggests that wind forces are not the primary driving force. The only other possibility is the stack pressure difference:

$$
\Delta P_{\text {stack }} \approx \rho \cdot g \cdot H \cdot\left(T_{\text {cavity }}-T_{\text {out }}\right) /\left(T_{\text {out }}+273\right) \approx 4-6 \mathrm{~Pa}
$$

The corresponding air flow path would be:

- infiltration through the outer leaf of the external wall into the external wall cavity; 
Pre-refereeing version July 2006. Revised version subsequently published in Building Services Engineering Research and Technology 282 (2007), 161-181.

- movement past the firestopping at the junction of external wall and party wall cavities, into the latter;

- movement up the party wall cavity;

- movement through the firestopping at the top of the party wall into the loft.

Each of these stages will generate a resistance to flow. The easiest to analyse is movement up the party wall. This is a 2-dimensional problem, but to make progress we will assume this flow to be 1 dimensional.

The ASHRAE Handbook ${ }^{(20)}$ section 34 gives the pressure drop due to friction in a duct as:

$\Delta P_{f} \approx\left(f . L / D_{h}\right) \cdot \frac{1}{2} \rho \cdot v^{2} \mathrm{~Pa}$

where:

$\mathrm{Re} \quad$ is the Reynold's number $\approx 66400 . D_{h} . v$

$f \quad$ is the friction factor $\approx 0.11\left(\varepsilon / D_{h}+68 / \mathrm{Re}\right)^{0.25}$ for the given range of $\mathrm{Re}$

$L \quad$ is the length of the equivalent duct

$\varepsilon \quad$ is the absolute roughness

For flow in the party wall cavity 
Pre-refereeing version July 2006. Revised version subsequently published in Building Services Engineering Research and Technology 282 (2007), 161-181.

$D_{h} \approx 2 . w_{\text {cavity }}=0.15 \mathrm{~m}$

$L \approx H=7.5 \mathrm{~m}$, and

$\varepsilon \approx 0.003 \mathrm{~m}$ (a value quoted for concrete ducts ${ }^{(20)} ; f$ is relatively insensitive to $\varepsilon)$.

On this basis, and with a flow speed of $0.4 \mathrm{~ms}^{-1}$, the pressure drop in the party wall cavity is of the order of $0.2 \mathrm{~Pa} \ll \Delta P_{\text {stack }}$.

Resistances associated with the other parts of the system are likely to be higher than this, but are impossible to calculate with any confidence. Based on estimates of the permeability of masonry walls published by Lecompte ${ }^{(21)}$, the pressure drop across the outer leaf and cavity of the external wall appears likely to be the largest, and could amount to 4 or $5 \mathrm{~Pa}$.

If this is the case, then the party wall cavity operates as an isobaric plenum contributing around $2 \%$ to the total pressure drop across the system. This in turn implies that the neutral plane in the system is at the top of the party wall and that the pressure difference driving air into the party wall cavity varies approximately linearly with distance below the roof.

The length of the flow path in the party wall cavity from foundation to $2^{\text {nd }}$ floor ceiling in house $E$ is approximately $7.5 \mathrm{~m}$. The corresponding transit time is in the region of 20 seconds. Assuming that air enters the party wall cavity at 
Pre-refereeing version July 2006. Revised version subsequently published in Building Services Engineering Research and Technology 282 (2007), 161-181.

outside temperature and that the flow is one-dimensional, the temperature of air in the cavity will rise exponentially toward $\bar{T}_{\text {in }}$, the mean internal temperature of the adjacent houses:

$T=\bar{T}_{\text {in }}-\left(\bar{T}_{\text {in }}-T_{\text {out }}\right) \cdot \exp (-t / \tau)$

and

$\phi=1-\exp (-t / \tau)$

where:

$\tau \approx \frac{w_{\text {cavity }} \cdot \rho \cdot c_{p}}{2 \cdot U_{\text {house-cavity }}}$

With $U_{\text {house-cavity }} \approx 2.1 \mathrm{Wm}^{-2} \mathrm{~K}^{-1}, \tau \approx 22 \mathrm{~s}$. We would therefore expect the temperature difference ratio in the cavity just below the plane of the loft insulation to be in the region of 0.6 . The observed temperature difference ratio is approximately 0.89 . 
Pre-refereeing version July 2006. Revised version subsequently published in Building Services Engineering Research and Technology 282 (2007), 161-181.

\subsection{Effective party wall $U$ value}

There are a number of different ways of stating the additional heat loss at Stamford Brook. We have already noted that the effective roof $U$ value in house $\mathrm{E}$ is approximately $1.8 \mathrm{Wm}^{-2} \mathrm{~K}^{-1}$. Given that the main thermal bypass mechanism appears to be associated with the party walls, the additional heat loss can also usefully be expressed as an effective party wall $U$ value. House $E$ has an extra heat loss of some $60 \mathrm{WK}^{-1}$ (Equation 16) and a total party wall area of $100 \mathrm{~m}^{2}$ (counting both party walls). The effective single-sided party wall $\mathrm{U}$ value is therefore approximately $0.6 \mathrm{Wm}^{-2} \mathrm{~K}^{-1}$.

\section{Relationship to earlier work}

We have found three earlier pieces of work of relevance to this study. The first is a study of heat loss though insulated roofs reported by Anderson ${ }^{(22)}$. This study involved measurements of heat flow, temperatures and heat fluxes in the roof of a two storey terraced house. Part of the roof was insulated with $80 \mathrm{~mm}$ and part with $100 \mathrm{~mm}$ of glass fibre between joists. For the purposes of this paper, the key result was:

“...a satisfactory agreement between measured and predicted heat loss, indicating that the standard calculation procedure gives a $U$ value 
Pre-refereeing version July 2006. Revised version subsequently published in Building Services Engineering Research and Technology 282 (2007), 161-181.

which represents a realistic estimate of the actual performance of an insulated roof."

Measured $U$ values were in most cases below predicted $U$ values due to solar gain. The paper contains no indication of unusually high loft temperatures. Personal communication with Anderson indicates that the terrace was built in the 1970 s, and that the party walls were constructed in cavity brick, changing to single brick above loft floor level. The apparent absence of a significant loft temperature excess would be consistent with this construction since the change to a solid wall would close the air bypass route.

The second is a study of experimental $U$ values of house walls by Siviour ${ }^{(4)}$. Siviour measured heat flux through external and party walls using heat flux sensors. The resulting empirical $U$ values for party walls ranged from 0.44 to "about $0.85 \mathrm{Wm}^{-2} \mathrm{~K}^{-1}$ ". The value measured at Stamford falls into the middle of this range. Siviour also noted that:

"The suggested reason for the heat loss through the party [and internal walls] is the movement of cold air in their cavities. Significant air movement between the loft and the cavity of one of the party walls through incomplete vertical movement joints was detected using a small hand-held smoke generator of the type used in airtightness testing." 
Pre-refereeing version July 2006. Revised version subsequently published in Building Services Engineering Research and Technology 282 (2007), 161-181.

The third is the study of energy conservation measures in the North Eastern USA at Twin Rivers ${ }^{(2,3)}$. This study reported a significant thermal bypass between basements and attics associated with the walls of terraced houses (row houses). These party walls were constructed in single leaf masonry, but the individual clinker blocks from which the party walls were constructed were hollow resulting in a series of continuous vertical slots. Despite partial blockage by mortar, these slots allowed air to flow from the basement into the attics of the houses. The party wall bypass conductance for a mid-terrace house (two party walls) was estimated as $74 \mathrm{WK}^{-1}{ }^{(2)}$. The Twin Rivers research team was able partially to block the party wall cavities in the plane of the roof insulation and demonstrate that this reduced attic temperatures and overall heat loss: the reduction in the party wall bypass conductance was estimated as $60 \%$. The air flow path in these houses differed from that at Stamford Brook, in that it did not involve a connection with the external wall. Nevertheless the flow was stack driven and its effect on heat loss similar to that observed at Stamford Brook.

Recent investigations of actual U values in UK housing ${ }^{(23,24)}$ have reported significant discrepancies between predicted and measured $U$ values of external elements, but appear not to have investigated heat losses associated with cavity party walls. 
Pre-refereeing version July 2006. Revised version subsequently published in Building Services Engineering Research and Technology 282 (2007), 161-181.

\section{Conclusions}

This paper has presented empirical evidence of a significant additional heat loss mechanism in terraced and semi-detached housing of masonry construction in the UK. This evidence comes from measurements made in a field trial of otherwise highly insulated mass housing at Stamford Brook in the winter of 2005/6. At its simplest, the evidence consists of observations of high loft temperatures observed during co-heating tests in two houses at Stamford Brook. It is independent of the quality of our subsequent speculation on possible causal mechanisms and is therefore robust.

For the house which was examined in the greatest detail (house E, a three storey mid-terrace house with two cavity party walls), the phenomenon would appear to add almost $60 \mathrm{WK}^{-1}$ to the total heat loss coefficient. This is the largest single heat loss route in this house. It exceeds both the predicted fabric heat loss and the ventilation heat loss and exceeds the heat loss through the windows and doors by more than a factor of 2 . The additional heat loss can be expressed as an effective roof $\mathrm{U}$ value. At $1.8 \mathrm{Wm}^{-2} \mathrm{~K}^{-1}$ this is more than ten times higher than the notional roof $U$ value.

We conclude that the roof insulation is being bypassed by one or more heat transfer mechanisms. The evidence clearly indicates that most of the bypassing is associated with the party walls. The additional heat loss can therefore usefully be expressed as an effective party wall $U$ value. The 
Pre-refereeing version July 2006. Revised version subsequently published in Building Services Engineering Research and Technology 282 (2007), 161-181.

effective single-sided party wall $\mathrm{U}$ value is approximately $0.6 \mathrm{Wm}^{-2} \mathrm{~K}^{-1}$ - more than twice the calculated external wall $U$ value in these houses. Direct measurements of air speeds in the party wall cavity were not made, but a variety of indirect evidence and analysis indicates that most of the bypass heat flow is associated with stack driven air movement in the party wall cavities.

An obvious implication of this result is that heat loss from terraced houses at Stamford Brook is significantly higher than for detached houses of the same basic design. We do not know what proportion of the UK housing stock is affected by this mechanism, because the construction of masonry party walls has varied over the years. Party walls in the solid-walled stock are invariably of solid construction. Even in cavity walled construction, until the 1960s, it was not uncommon for party walls in loft spaces and gables to be solid. It is clear that the relative importance of the effect is greatest in dwellings built to the most recent energy performance standards which have resulted in significant reductions in fabric heat loss compared to the housing stock as a whole.

The most reliable estimates of stock mean internal temperature in UK dwellings are based on estimates of delivered energy input, space heating system efficiency and utilisation of free heat gains over the heating season are due to Shorrock \& Utley ${ }^{(25)}$. Errors in specific heat loss will therefore have led to overestimates of mean internal temperature in house types with cavity party walls. Semi-detached dwellings are the easiest group to analyse in this 
Pre-refereeing version July 2006. Revised version subsequently published in Building Services Engineering Research and Technology 282 (2007), 161-181.

respect, since most have been built since the advent of party wall construction. Shorrock's \& Utley's estimate of the mean heat loss of this group in 2001 was $276 \mathrm{WK}^{-1}$, and their estimate of the stock mean heating season internal temperature was $19^{\circ} \mathrm{C}$. Assuming that each such dwelling had $40 \mathrm{~m}^{2}$ of cavity party wall with an effective $U$ value of $0.6 \mathrm{Wm}^{-2} \mathrm{~K}^{-1}$, the internal temperature in this group will have been overestimated by approximately $0.8^{\circ} \mathrm{C}$. This is not so large a source of error that it would have been detected by comparison with spot measurements of internal temperature or with the limited stock of continuously monitored dwelling temperatures. It may, however, be significant in the context of arguments about trends in internal temperatures in UK housing.

It would be straightforward to prevent bypassing of roof insulation by party walls: for example by filling the cavity of the party wall with mineral fibre, or by inserting a flexible membrane or plastic sleeved cavity closer across the cavity in the plane of the roof insulation. Before widespread implementation, it would be crucial to confirm empirically the efficacy of such measures and their impacts on buildability and acoustic performance.

The identification and approximate quantification of this heat loss mechanism has emerged shortly after the publication of the 2006 amendment to Part $L$ of the Building Regulations and its supporting documentation. In the UK context it is therefore fortunate that we can see no need to amend the new regulations. 
Pre-refereeing version July 2006. Revised version subsequently published in Building Services Engineering Research and Technology 282 (2007), 161-181.

Amendment is however likely to be required in BS EN ISO 6946, BR 443, the conventions used in the calculation of the Dwelling $\mathrm{CO}_{2}$ Emission Rate ${ }^{(7)}$ and in supporting documentation for the system of accredited construction details that forms part of the wider regulatory framework for building energy performance in the UK.

The most important remaining scientific questions relate, in our view, to the nature of the air flow in the external wall and party wall cavities. We have estimated the speed of air flow in the cavity based on measured temperatures and on the assumption that flow is uniform, and have discounted the possibility of one or more convective loops within cavity. A full understanding of the observed phenomena requires direct simultaneous measurement of temperature and flow fields in both cavities. It is anticipated that the further work at Stamford Brook scheduled for the winter of 2006/07 will help to clarify these and other important issues.

\section{Acknowledgements}

The authors wish to acknowledge the support of their partners in the Stamford Brook Project, National Trust, Redrow Homes, Bryant Homes/Taylor Woodrow, Vent Axia, CITB, NHBC and the Concrete Block Association. They particularly wish to acknowledge the positive cooperation of both developers and the 
Pre-refereeing version July 2006. Revised version subsequently published in Building Services Engineering Research and Technology 282 (2007), 161-181.

forbearance and goodwill of the occupants of the dwellings adjacent to the test houses throughout the work described here. The authors also wish to acknowledge the cooperation of the Bartlett School of Graduate Studies, led by Prof Tadj Oreszczyn, which resulted in the loan, at short notice, of a high resolution infra-red camera.

The Stamford Brook project is funded by the project partners and the DTI and DCLG under the Partners in Innovation Programme and the Building Regulations Research Framework.

\section{References}

1 Lowe RJ \& Bell M. Evaluating the Impact of an Enhanced Energy

Performance Standard on Load-Bearing Masonry Domestic

Construction, Partners in Innovation Cl 39/3/663, Project

Implementation Plan. Leeds: Centre for the Built Environment, Leeds Metropolitan University, 2002.

2 Socolow R ed. Saving Energy in the Home: Princeton's Experiments at Twin Rivers. Cambridge MA: Ballinger, 1978.

3 Harrje DT, Dutt GS \& Beyea JE. Locating and eliminating obscure but major energy losses in residential housing. ASHRAE Transactions 1979; 85 (2): 521-534. 
Pre-refereeing version July 2006. Revised version subsequently published in Building Services Engineering Research and Technology 282 (2007), 161-181.

4 Siviour JB. Experimental U-Values of Some House Walls. Building Services, Engineering, Research \& Technology 1994; 15 (1): 35-36.

5 Anderson BR. Conventions for U-value calculations, BR 443, 2nd edition. Watford: BRE, 2006.

$6 \quad$ BS EN ISO 6946: 1997 Building components and building elements Thermal resistance and thermal transmittance - Calculation method.

7 ODPM. Building Regulations Approved Document L1A: Conservation of Fuel and Power in New Dwellings. London: ODPM, 2006.

http://www.odpm.gov.uk/ (accessed 31 May 2006).

8 Lowe RJ \& Bell M. A Trial of Dwelling Energy Performance Standards for 2008: Prototype standards for energy and ventilation performance. Leeds: Centre for the Built Environment Leeds Metropolitan University, 2001

9 Wingfield J, Bell M, Bell JM \& Lowe RJ. Evaluating the Impact of an Enhanced Energy Performance Standard on Load-Bearing Masonry Domestic Construction, Partners in Innovation Cl 39/3/663, Interim Report Number 5 - Post Construction Testing and Envelope Performance. Leeds: Centre for the Built Environment, Leeds Metropolitan University, 2006. 
Pre-refereeing version July 2006. Revised version subsequently published in Building Services Engineering Research and Technology 282 (2007), 161-181.

10 Roberts D, Bell M \& Lowe RJ. Evaluating the Impact of an Enhanced Energy Performance Standard on Load-Bearing Masonry Construction, Partners in Innovation Cl 39/3/663, Interim Report No 2 - Design Process, Leeds: Centre for the Built Environment, Leeds Metropolitan University, 2004.

11 Roberts D, Andersson M, Lowe RJ, Bell M \& Wingfield J. Evaluating the Impact of an Enhanced Energy Performance Standard on Load-Bearing Masonry Domestic Construction, Partners in Innovation Cl 39/3/663, Interim Report Number 4 - Construction Process. Leeds: Centre for the Built Environment, Leeds Metropolitan University, 2005.

12 Roberts D, Johnston D \& Isle JA. A Novel Approach to Achieving Airtightness in Drylined Load-bearing Masonry Dwellings, Building Services, Engineering, Research \& Technology 2005; 26 (1): 63-69.

13 Stephen RK. Airtightness in UK dwellings, IP 1/00. Watford: BRE, 2000.

14 Grigg P. Assessment of energy efficiency impact of Building Regulations compliance, Client Report 219683. Watford: BRE, 2004.

15 OPDM. Building Regulations Approved Document E: Resistance to the Passage of Sound. London: ODPM, 2003. http://www.odpm.gov.uk/ (accessed 31 May 2006). 
Pre-refereeing version July 2006. Revised version subsequently published in Building Services Engineering Research and Technology 282 (2007), 161-181.

16 ODPM. Building Regulations Approved Document L1: Conservation of Fuel and Power in Dwellings. London: ODPM, 2002.

17 Lowe RJ. Ventilation strategy, energy use and $\mathrm{CO}_{2}$ emissions in dwellings - a theoretical approach. Building Services, Engineering, Research \& Technology 2000; 21 (3): 181-187.

18 Palmiter LS, Hamilton LB \& Holtz MJ. Low cost performance evaluation of passive solar buildings, SERI/RR 63-223. Golden, Colorado: Solar Energy Research Institute, 1979.

19 Carlsson B, Elmroth A \& Engvall P. Air Tightness and Thermal Insulation - Building Design Solutions. Stockholm: Byggforskningrådet (Swedish Council for Building Research), 1980.

202001 ASHRAE Handbook: Fundamentals. Atlanta GA: ASHRAE.

21 Lecompte JGN. Airtightness of masonry walls. In: Proceedings 8th AIVC Conference, Überlingen, DBR. AIVC, September 1987.

22 Anderson BR. Measurements of the heat loss through an insulated roof. Building Services Engineering Research \& Technology 1981; 2 (2): 65-72. 
Pre-refereeing version July 2006. Revised version subsequently published in Building Services Engineering Research and Technology 282 (2007), 161-181.

23 Doran S. Field investigations of the thermal performance (U-values) of construction elements - as built, BRE Report 78132. Watford: BRE, 2000.

24 Doran S. Improving the thermal performance of buildings in practice, BRE Client Report 222392. Watford: BRE, 2005.

25 Shorrock LD \& Utley JI. Domestic Energy Factfile 2003, BR457.

Watford: BRE, 2003. 
Pre-refereeing version July 2006. Revised version subsequently published in Building Services Engineering Research and Technology 282 (2007), 161-181.

\section{Tables}

Table 1 Summary of house form and dimensions

\begin{tabular}{lclccccc}
\hline Developer & Plot No. & Form & $\begin{array}{l}\text { Gross } \\
\text { floor area } \\
\left(\mathbf{m}^{2}\right)\end{array}$ & $\begin{array}{l}\text { Volume } \\
\left(\mathbf{m}^{3}\right)\end{array}$ & $\begin{array}{l}\text { Plan } \\
\text { depth } \\
(\mathbf{m})\end{array}$ & $\begin{array}{l}\text { Plan } \\
\text { width } \\
(\mathbf{m})\end{array}$ & $\begin{array}{l}\text { Glazing } \\
\text { ratio }\end{array}$ \\
\hline Bryant & $\mathrm{A}$ & 73 & 190 & 7.7 & 4.7 & 0.17 \\
Redrow & $\begin{array}{l}\text { semi- } \\
\text { detached, } \\
2 \text { storey, } \\
\text { 3 bedroom } \\
\text { mid-terrace, } \\
\text { 3 storey, } \\
\text { 3 bedroom }\end{array}$ & 106 & 267 & 6.9 & 5.1 & 0.19 \\
\hline
\end{tabular}

Table 2 Measured air permeability in co-heating test houses

\begin{tabular}{ccccc}
\hline Plot No. & $\begin{array}{l}\text { Permeability before } \\
\left(\mathbf{m h}^{-1} @ \mathbf{5 0} \mathrm{Pa}\right)\end{array}$ & $\begin{array}{l}\text { Permeability after } \\
\left(\mathbf{m h}^{-1} @ \mathbf{5 0 ~ P a}\right)\end{array}$ & $\begin{array}{l}\text { Increase in } \\
\text { permeability } \\
\left(\mathbf{m h}^{-1} @ \mathbf{5 0 ~ P a}\right)\end{array}$ & $\begin{array}{l}\text { Consequent } \\
\text { increase in heat loss } \\
\text { coefficient (W/K) }\end{array}$ \\
\hline $\mathrm{A}$ & 3.3 & 4.2 & 0.9 & 0.6 \\
$\mathrm{E}$ & 5.3 & 5.9 & 0.6 & 0.8 \\
\hline
\end{tabular}

Table 3 Estimated heat loss coefficients in co-heating test houses

\begin{tabular}{ccccc} 
Plot No. & $\begin{array}{l}\text { Ventilation heat } \\
\text { loss coefficient } \mathbf{c}_{\mathrm{v}} \\
\left(\mathbf{W K}^{-1}\right)\end{array}$ & $\begin{array}{l}\text { Fabric heat loss } \\
\text { coefficient } \mathbf{c}_{\mathrm{f}} \\
\left(\mathbf{W K}^{-1}\right)\end{array}$ & $\begin{array}{l}\text { Linear thermal } \\
\text { transmission } \\
\text { included in } \mathbf{c}_{\mathrm{f}} \\
\left(\mathbf{W K}^{-1}\right)\end{array}$ & $\begin{array}{l}\text { Total heat loss } \\
\text { coefficient } \mathbf{c}_{\mathrm{v}}+\mathbf{c}_{\mathrm{f}} \\
\left(\mathbf{W K}^{-1}\right)\end{array}$ \\
\hline $\mathrm{A}$ & 13.2 & 50.6 & 6.0 & 63.8 \\
$\mathrm{E}$ & 20.3 & 54.9 & 5.8 & 75.2 \\
\hline
\end{tabular}


Pre-refereeing version July 2006. Revised version subsequently published in Building Services Engineering Research and Technology 282 (2007), 161-181.

Table 4 Co-heating test equipment specification - Dwellings

\begin{tabular}{lll} 
Component & Equipment Used & Equipment Specification \\
\hline Datalogger & Eltek RX250 Receiver Logger & 250 channel radio receiver logger \\
& & Set at 10 minute logging interval \\
GSM Modem & Wavecom M1206B GSM Modem & - \\
Temperature Sensor & Eltek GC-10 Temp/RH Radio Transmitter & Minimum of 1 per floor \\
kWh Meter & Schlumberger SPA02 & 10 Wh pulse output \\
& & 1 per floor \\
Pulse Transmitter & Eltek GS-62 Pulse Radio Transmitter & 1 per kWh meter \\
Thermostat & Honeywell T4360B Thermostat & $16 \mathrm{~A}$ load capacity \\
& & Mounted on a tripod at 1m \\
Fan Heater & & 1 per kWh meter \\
& & 3 kW max heat output
\end{tabular}

Table 5 Co-heating test equipment specification - Weather station

\begin{tabular}{lll}
\hline Weather Station Component & Equipment Used & Specification \\
\hline Datalogger & Eltek RX250 Receiver Logger & 250 channel radio receiver logger \\
& & Set at 10 minute logging interval \\
GSM Modem & Wavecom M1206B GSM Modem & - \\
Temperature/Humidity Gauge & Rotronic Hygroclip S3 External & Positioned at 2m on 4m mast \\
& Temperature/Humidity Sensor & Protected by Stephenson \\
& & Radiation Screen \\
Temperature/Humidity Transmitter & Eltek GS-13 Hydroclip Radio Transmitter & - \\
Pyranometer & Kipp \& Sonnen CM3 pyranometer & Vertical Orientation \\
& & South Facing \\
Pyranometer Transmitter & & Positioned at 3m on 4m mast \\
\hline
\end{tabular}


Pre-refereeing version July 2006. Revised version subsequently published in Building Services Engineering Research and Technology 282 (2007), 161-181.

Table 6 Comparison of predicted and measured heat loss coefficients

\begin{tabular}{cccc} 
Plot No. & $\begin{array}{l}\text { Predicted heat loss } \\
\text { coefficient }\left(\mathbf{W K}^{-1}\right)\end{array}$ & $\begin{array}{l}\text { Measured heat loss } \\
\text { coefficient }\left(\mathbf{W K}^{-1}\right)\end{array}$ & $\begin{array}{l}\text { Difference between } \\
\text { predicted and measu } \\
\left(\text { WK }^{-1}\right)\end{array}$ \\
\hline A & 63.8 & $111.7 \pm 5.9$ & $47.9(75 \%)$ \\
E & 75.2 & $153.4 \pm 3.3$ & $78.2(103 \%)$ \\
\hline
\end{tabular}


Pre-refereeing version July 2006. Revised version subsequently published in Building Services Engineering Research and Technology 282 (2007), 161-181.

\section{Figure Captions}

Figure 1 External and party wall construction for house E - Sketch plan section

Figure 2 Plan and elevation drawings for house $\mathrm{A}$

Figure 3 Plan and elevation drawings for house $\mathrm{E}$

Figure 4 Scatter plot of heating power versus $\Delta T$ for house $\mathrm{A}$ (24 hour averages)

Figure 5 Scatter plot of heating power versus $\Delta T$ for house $E$ (24 hour averages)

Figure 6 Infra-red and visible spectrum images of the top of party wall E-F taken in the loft of house $\mathrm{E}$, with external temperature in the range $3-5^{\circ} \mathrm{C}$

Figure 7 Infra-red and visible spectrum images of the bottom of party wall E-F taken in the loft of house $\mathrm{E}$, with external temperature in the range $3-5^{\circ} \mathrm{C}$

Figure 8 Extended temperature measurements in house $\mathrm{E}$

Figure 9 Simple models of heat flows through loft (assuming no heat transfer between dwellings) 
Pre-refereeing version July 2006. Revised version subsequently published in Building Services Engineering Research and Technology 282 (2007), 161-181.

\section{Figures}

Figure 1

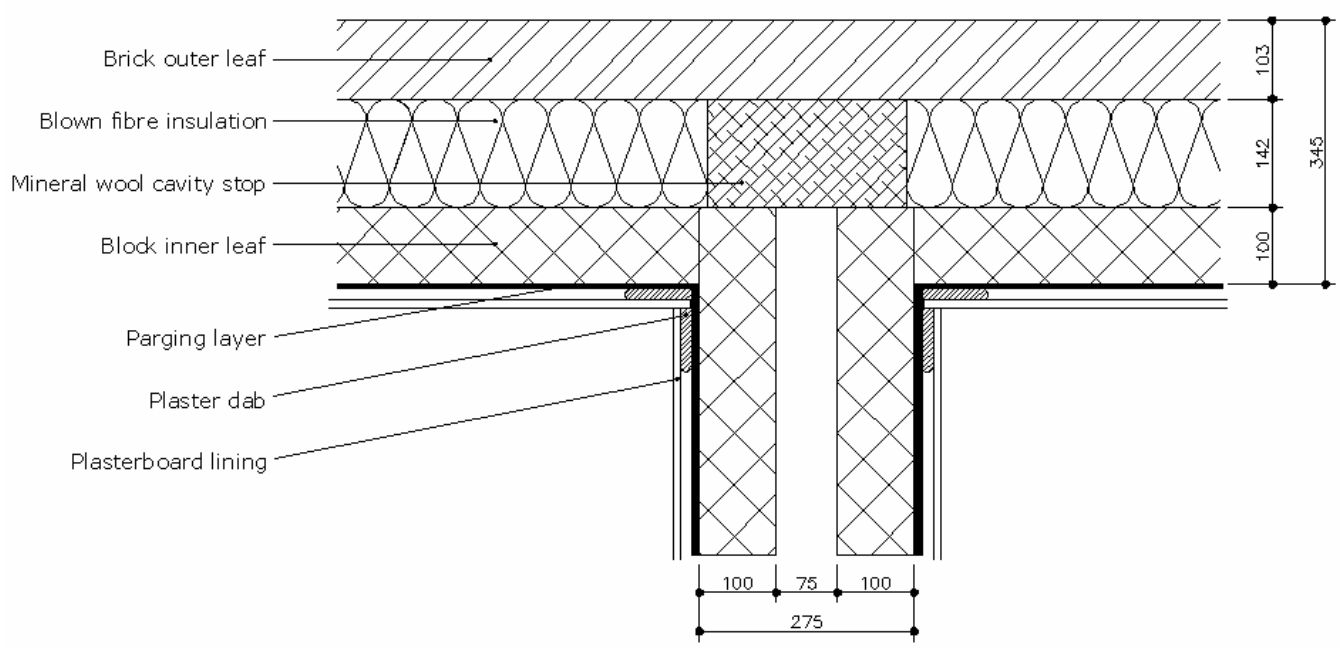

Figure 2
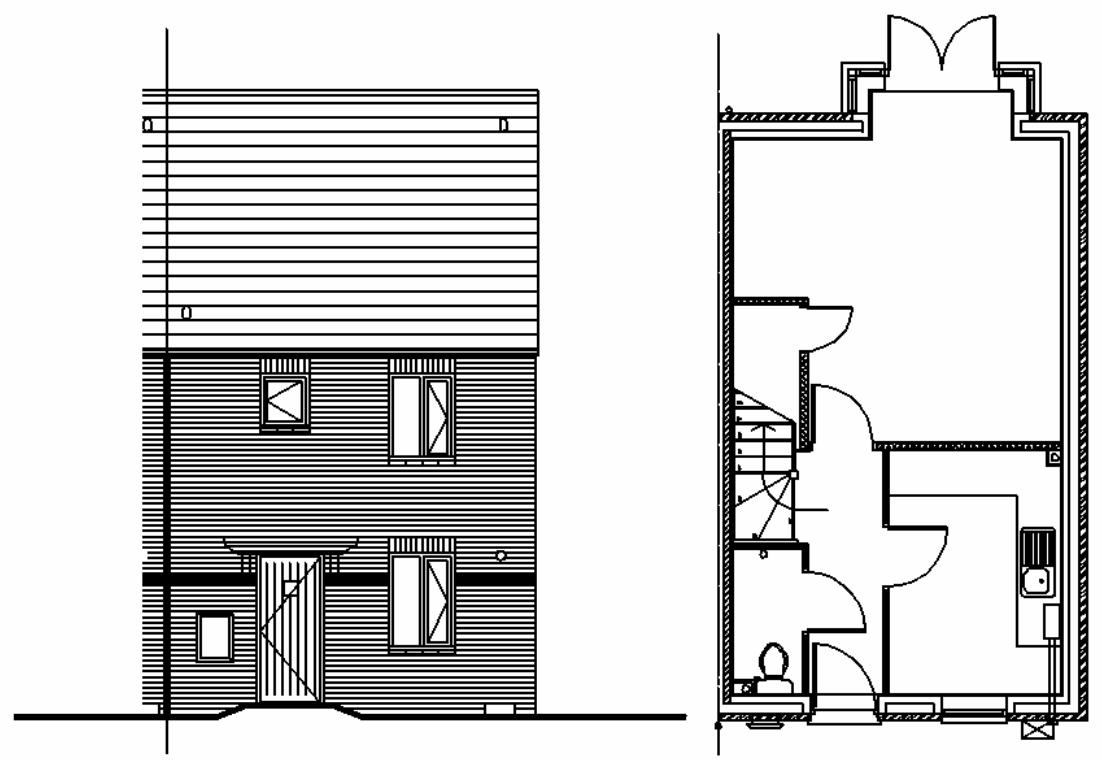
Pre-refereeing version July 2006. Revised version subsequently published in Building Services Engineering Research and Technology 282 (2007), 161-181.

Figure 3
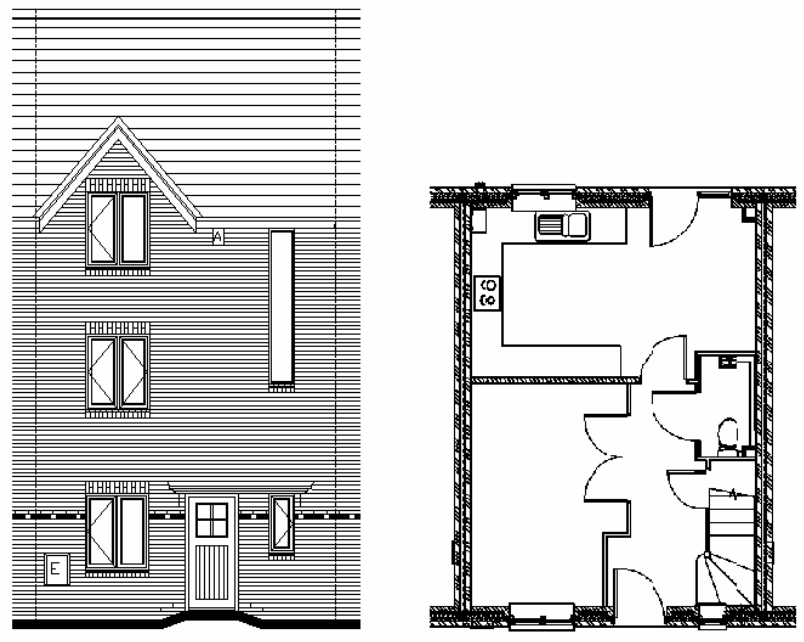

Figure 4

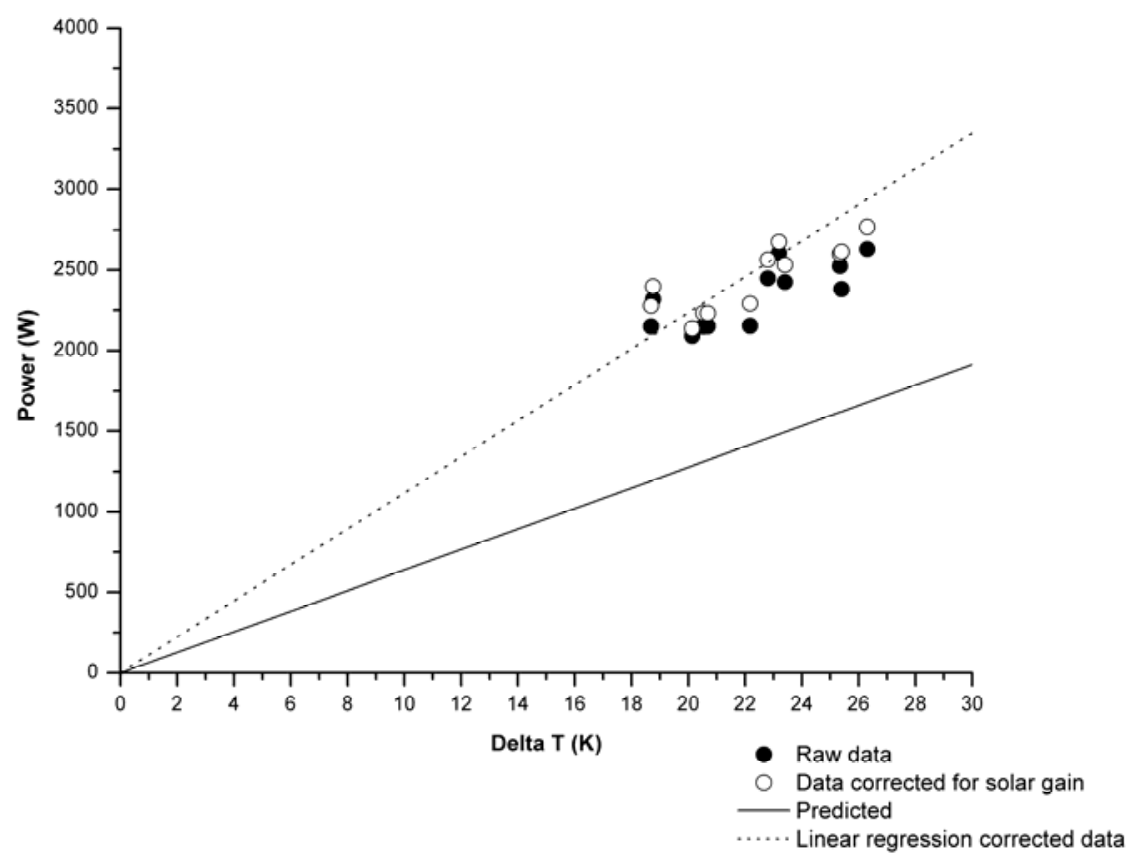


Pre-refereeing version July 2006. Revised version subsequently published in Building Services Engineering Research and Technology 282 (2007), 161-181.

Figure 5

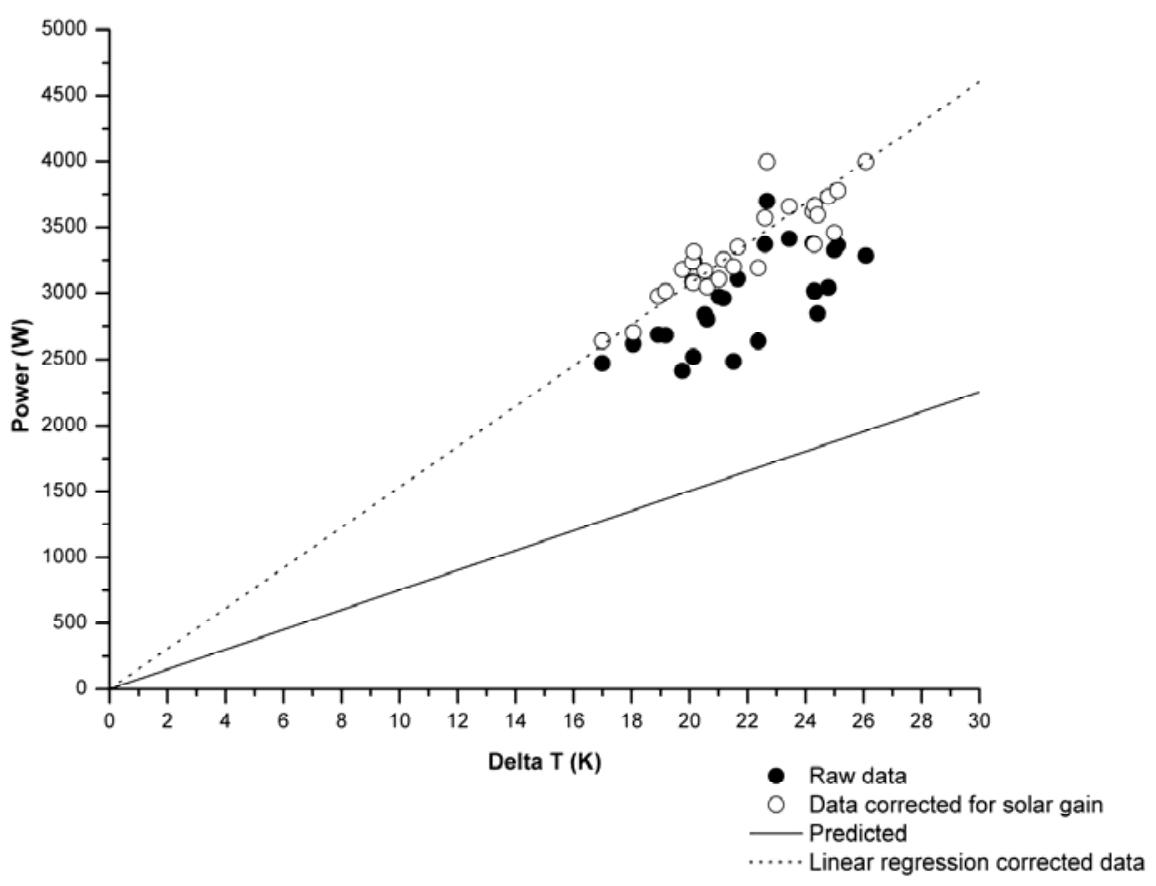

Figure 6
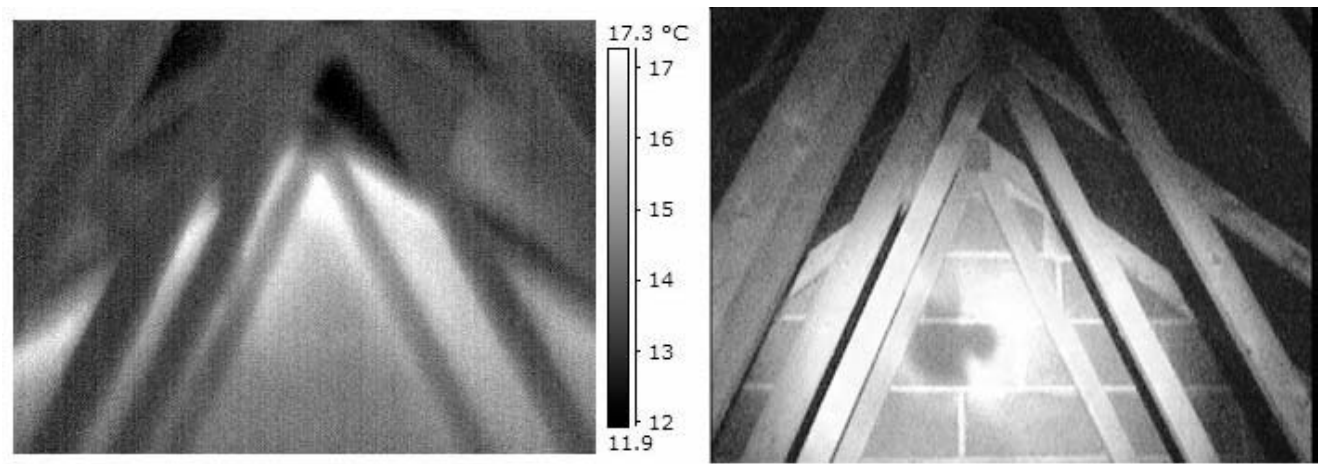

Figure 7 
Pre-refereeing version July 2006. Revised version subsequently published in Building Services Engineering Research and Technology 282 (2007), 161-181.
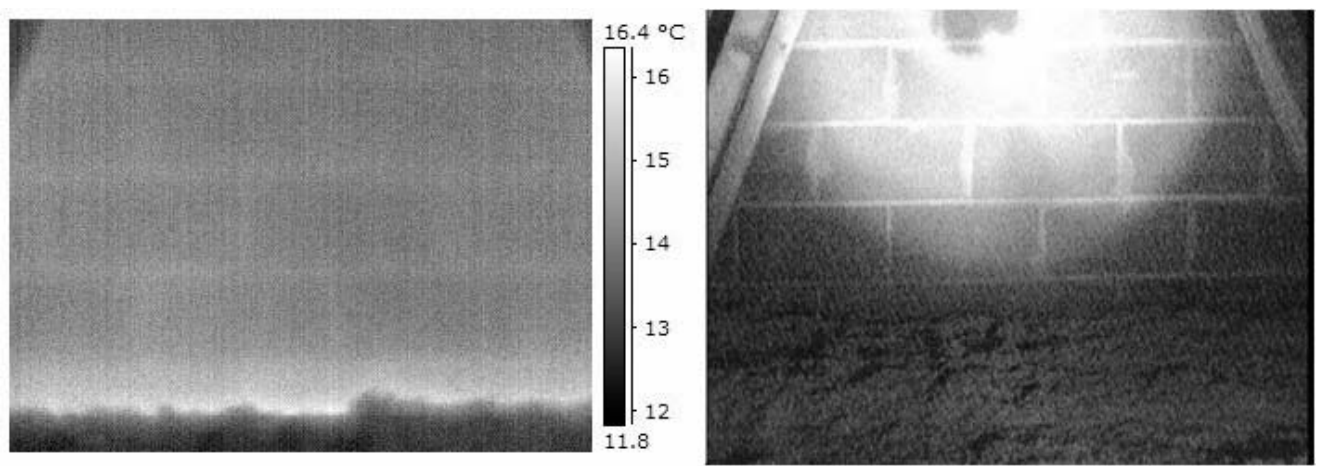

Figure 8

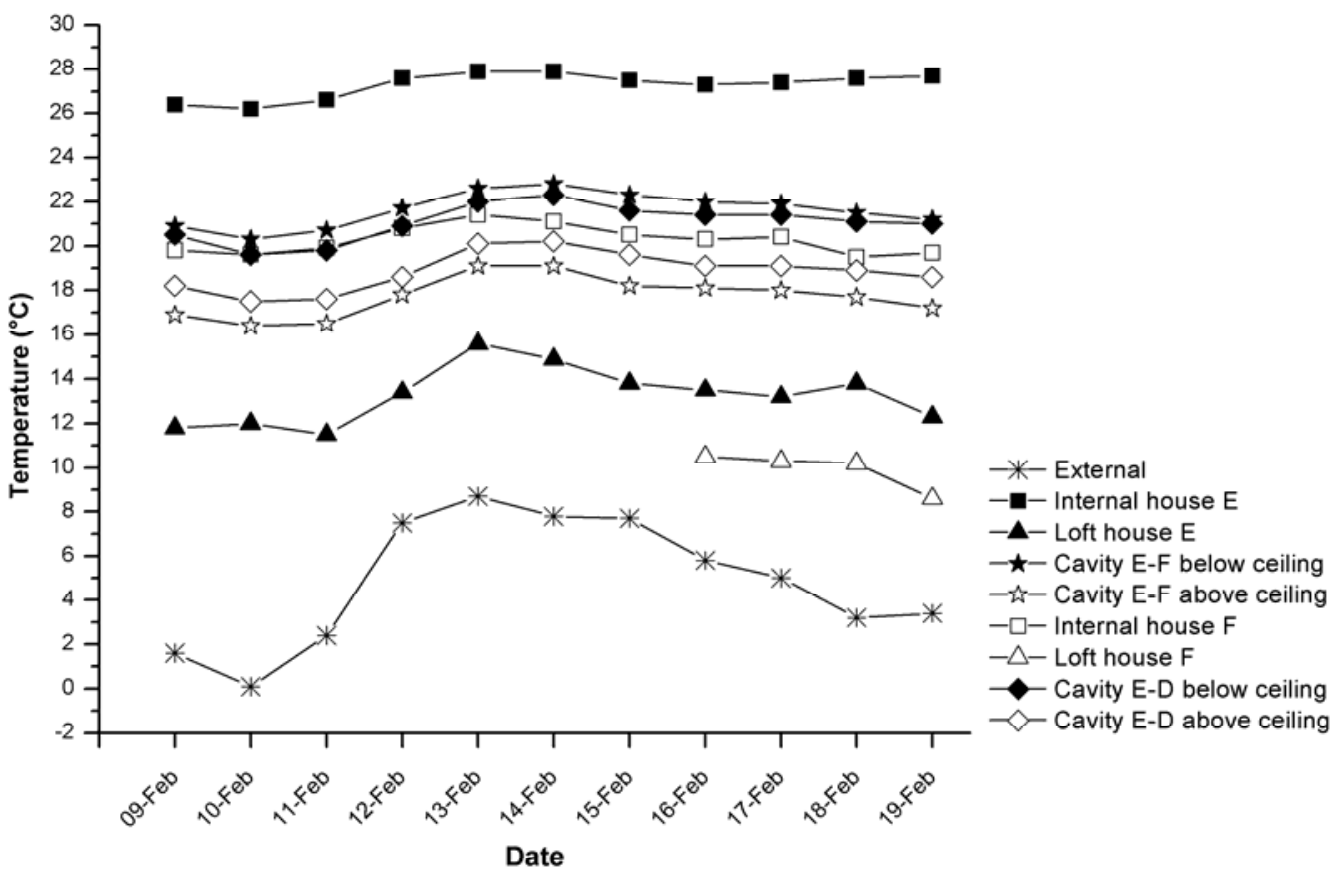


Pre-refereeing version July 2006. Revised version subsequently published in Building Services Engineering Research and Technology 282 (2007), 161-181.

Figure 9

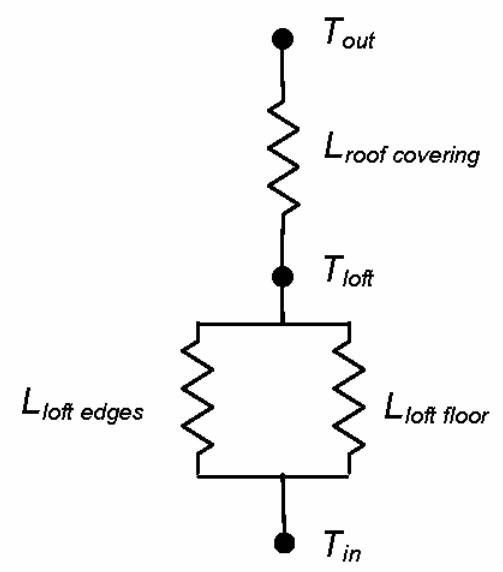

(a) Conventional model

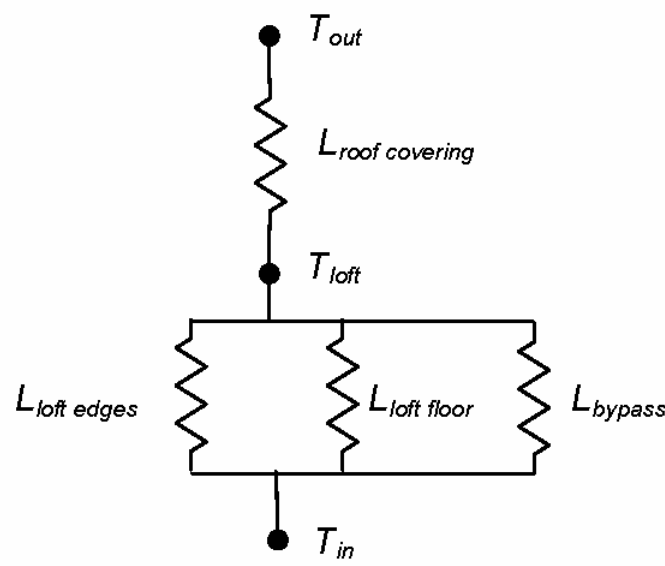

(b) Thermal bypass model 